\title{
KESESUAIAN ERGONOMI MEJA BELAJAR DENGAN DATA ANTROPOMETRI SISWA DI SEKOLAH DASAR JAKARTA UTARA
}

\author{
Desmyanti $^{1}$, Robi Irawan ${ }^{2}$, Yunisa Astiarani ${ }^{3}$, Heidy $^{4}$ \\ ${ }^{1}$ Fakultas Kedokteran dan Ilmu Kesehatan, Universitas Katolik Indonesia Atma Jaya, Jl. Pluit \\ Raya No. 2, Jakarta 14440, Indonesia (E-mail: tarihoranmia2@gmail.com) \\ ${ }^{2}$ Departemen Anatomi, Fakultas Kedokteran dan Ilmu Kesehatan, Universitas Katolik \\ Indonesia Atma Jaya, Jl. Pluit Raya No. 2, Jakarta 14440, Indonesia (E-mail: \\ robi.irawan@atmajaya.ac.id) \\ ${ }^{3}$ Departemen Ilmu Kesehatan Masyarakat dan Gizi, Fakultas Kedokteran dan Ilmu \\ Kesehatan, Universitas Katolik Indonesia Atma Jaya, J1. Pluit Raya No. 2, Jakarta 14440, \\ Indonesia (E-mail: yunisa.astiarani@atmajaya.ac.id) \\ ${ }^{4}$ Departemen Fisiologi/Fisika, Fakultas Kedokteran dan Ilmu Kesehatan, Universitas Katolik \\ Indonesia Atma Jaya, Jl. Pluit Raya No. 2, Jakarta 14440, Indonesia (E-mail: \\ haihei_dee@yahoo.com)
}

Received: Januari 2021; Accepted: April 2021; Published: Juni 2021

\begin{abstract}
ABSTRAK
Analisis kesesuaian ergonomi meja belajar dengan antropometri anak belum banyak diterapkan di sekolah-sekolah dasar di Indonesia, padahal meja belajar yang ergonomis penting untuk kesehatan tulang belakang dalam masa pertumbuhan. Penelitian ini bertujuan untuk mengevaluasi kesesuaian ergonomi meja belajar dengan data antropometri anak sekolah dasar di Jakarta Utara.Penelitian ini dilakukan secara cross sectional dan melibatkan 98 siswa dari kelas 1 sampai 6 SD di sebuah sekolah dasar di Jakarta Utara. Alat ukur yang digunakan adalah pita meteran. Terdapat 100\% ketidaksesuaian antara ergonomi meja belajar dengan data antropometri anak sekolah dasar yang dianalisis melalui persentil data antropometri. Panjang meja memiliki rerata presentase ketidaksesuaian terbesar (61.1\%) dan presentase ketidaksesuaian panjang meja yang tertinggi terdapat pada kelas 1 (87.3\%). Terdapat ketidaksesuaian antara ergonomi meja terhadap antropometri anak sekolah dasar di Jakarta Utara
\end{abstract}

Kata Kunci: ergonomi, antropometri, anak, sekolah dasar

\section{PENDAHULUAN}

Pemerintah mewajibkan anak-anak Indonesia untuk bersekolah selama 9 tahun sehingga anak-anak Indonesia terbiasa belajar dan menghabiskan waktu di sekolah sekitar 6 jam per harinya (Irham dan Mulyadi, 2015). Dalam kegiatan belajar di sekolah, peserta didik menggunakan meja 
Jurnal Kesehatan Masyarakat dan Lingkungan Hidup

ISSN: 2528-4002 (media online)

ISSN: 2355-892X (print)

Online: http://e-journal.sari-mutiara.ac.id/index.php/KesehatanMasyarakat

DOI: https://doi.org/10.51544/jkmlh.v6i1.1682

belajar. Meja belajar sekolah yang tidak ergonomis dapat menyebabkan ketidaknyamanan bagi siswa, serta dapat mengganggu konsentrasi. Akibat lebih lanjut dapat menimbulkan rasa sakit di bagian terutama bagian punggung dan pinggang belakang dan mengganggu kesehatan tulang belakang (Irham dan Mulyadi, 2015).

Penelitian yang dilakukan oleh Yanto dkk (2008) menunjukkan bahwa anak-anak sekolah mengeluhkan kondisi ketidaknyamananan yang dirasakan pada punggung dan pinggang belakang akibat ketidaksesuaian antara desain mebel sekolah dengan ukuran antropometri mereka (Yanto dkk., 2008). Penelitian yang dilakukan di Yogyakarta juga menunjukkan bahwa efek ketidaksesuaian antara desain mebel sekolah dengan antropometri peserta didiknya menimbulkan keluhan sakit pada bagian punggung, pinggang, leher bagian atas, siku kiri dan lutut kanan. Beberapa penelitian lain yang telah dilakukan menunjukkan bahwa selain desain ukuran mebel sekolah juga yang tidak sesuai dengan antropometri siswa (Altaboli dkk., 2015; Macedo dkk., 2015; Rosyidi dkk., 2016; Jennie dkk., 2017; Novita dkk., 2018). Siswa yang menggunakan meja yang lebih tinggi dari yang direkomendasikan, maka mereka harus melenturkan lengan dan mengangkat bahu.
Akibatnya, daerah bahu memiliki lebih banyak beban kerja sehingga siswa dapat mengeluhkan ketidaknyamanan, nyeri dan postur tulang belakang yang tidak seimbang.

Tiga prinsip desain utama biasanya digunakan untuk merancang produk yang berbeda di mana pengukuran antropometri dipertimbangkan: 'desain untuk individu yang ekstrim'; 'Mendesain untuk interval yang dapat disesuaikan'; dan 'desain untuk rata-rata' (Sanders dan McCormick, 1998). Desain untuk individu ekstrim disebut sebagai desain yang diperuntukkan pada populasi maksimum (persentil ke-95/p95 antropometri laki-laki) dan populasi minimum (persentil ke-5/p5 antropometri perempuan) (Khaspuri, Sau, dan Dhara, 2007). Di sisi lain, perancangan untuk interval yang dapat disesuaikan mengikuti p5 antropometri perempuan hingga p95 antropometri laki-laki, sehingga 90\% peserta dapat diakomodasi (Alrashdan, Alsudairi, dan Alqaddoumi 2014; Kothiyal dan Tettey 2001). Desain rata-rata adalah prinsip yang paling banyak digunakan namun tidak praktis karena hanya 50\% populasi diakomodasi olehnya. Oleh karena itu, saat mendesain mebel menggunakan prinsip interval yang dapat disesuaikan adalah prinsip paling baik dan menghasilkan solusi yang efektif. 
Studi mengenai kesesuaian ergonomi meja belajar dengan antropometri siswa masih belum dianggap penting dengan tidak adanya peraturan khusus yang mengaitkan aspek tersebut dalam kriteria sekolah sehat. Padahal pengukuran antropometri siswa di sekolah merupakan hal yang harus diperhatikan khususnya bagi populasi di Asia dalam merancang mebel sekolah yang ergonomis untuk mencegah masalah kesehatan yang sering ditimbulkan dan kelainan tulang belakang dimasa yang akan dating (Taifa dkk., 2017).

Studi ini dilakukan di sebuah sekolah dasar (SD) swasta di Jakarta Utara untuk mengevaluasi ukuran ergonomi meja belajar dan ukuran antropometri siswa dengan tujuan menilai potensi ketidaksesuaian ergonomi meja belajar sekolah yang dapat berakibat pada kelainan muskuloskeletal.

\section{METODE}

Studi potong lintang dilakukan di salah satu SD swasta di Jakarta Utara. Responden dalam penelitian ini adalah siswa yang memenuhi kriteria inklusi yaitu siswa kelas 1 hingga $6 \mathrm{SD}$ dan kooperatif saat pengukuran antropometri, sedangkan kriteria eksklusinya adalah siswa yang memiliki kelainan pada tulang belakang dan keterbatasan fisik. Sampel dipilih secara random dengan teknik simple random sampling berdasarkan perhitungan besar sampel yang telah ditentukan sebelumnya sebesar 98 siswa.

Pengukuran ergonomi dilakukan terhadap enam tipe dan ukuran meja belajar yang digunakan di sekolah tersebut. Data ergonomi meja yang diukur, yaitu tinggi meja belajar, tinggi kursi, tinggi laci, panjang meja belajar, dan lebar meja belajar. Meja dan kursi yang digunakan dalam satu kelas memiliki ukuran dan desain yang sama.

\section{Tinggi Meja Belajar}

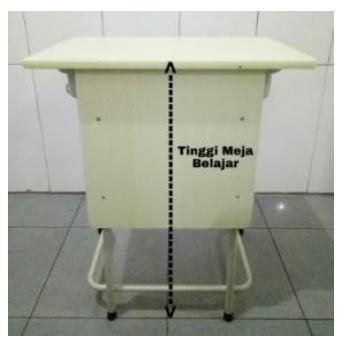

\section{Gambar 1. Tinggi Meja Belajar}

Tinggi meja belajar adalah jarak vertikal dari lantai sampai dengan tepi atas meja belajar. Tinggi meja belajar harus disesuaikan dengan persentil $5^{\text {th }}-95^{\text {th }}$ dari tinggi siku duduk, kemudian ditambahkan dengan tinggi kursi (Taifa dkk., 2017) 


\section{Tinggi Kursi}

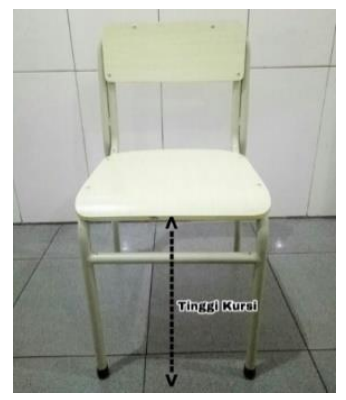

Gambar 2. Tinggi Kursi

Tinggi kursi adalah jarak vertikal dari lantai sampai dengan tepi atas kursi bagian depan. Tinggi kursi ini akan ditambah dengan persentil $5^{\text {th }}$ $95^{\text {th }}$ dari tinggi siku duduk (Taifa dkk., 2017).

3. Tinggi Laci

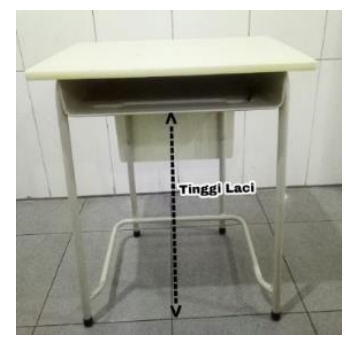

Gambar 3. Tinggi Laci

Tinggi laci adalah jarak vertikal dari lantai sampai dengan tepi bawah laci meja belajar. Tinggi laci ini akan disesuaikan dengan persentil $95^{\text {th }}$ dari tinggi lutut duduk (Devinasari dkk., 2019).

4. Panjang Meja Belajar

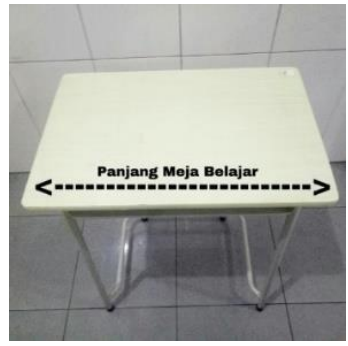

Gambar 4. Panjang Meja Belajar
Panjang meja belajar adalah jarak panjang meja belajar dari sisi yang satu sampai sisi yang lainnya. Panjang meja belajar ini akan disesuaikan dengan persentil $95^{\text {th }}$ dari lebar sisi bahu (Taifa dkk., 2017).

5. Lebar Meja Belajar

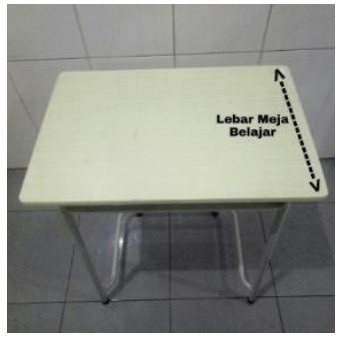

Gambar 5. Lebar Meja Belajar

Lebar meja belajar adalah jarak lebar meja belajar dari sisi yang satu sampai sisi yang lainnya. Lebar meja belajar akan disesuaikan dengan persentil $95^{\text {th }}$ dari ukuran panjang genggaman tangan ke depan anak laki-laki (Taifa dkk., 2017).

Setelah itu, data ergonomi meja belajar akan disesuaikan dengan data antropometri siswa, yang diukur dengan menggunakan pita meteran meteran pada 98 siswa pada Juli 2019, menggunakan kriteria persentil yang telah disebutkan diatas. Data antropometri yang diukur, yaitu tinggi siku duduk, tinggi lutut duduk, lebar sisi bahu, panjang genggaman tangan ke depan. 
1. Tinggi siku duduk

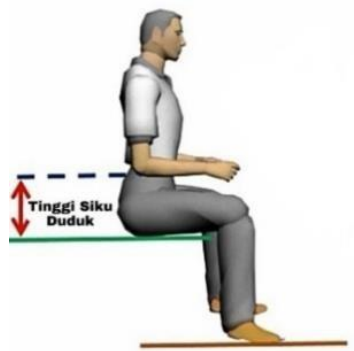

\section{Gambar 6. Tinggi Siku Duduk}

Tinggi siku duduk adalah jarak vertikal dari alas duduk ke bagian bawah lengan bawah (under side of the elbow) (Hadiwiyono, 2015). Tinggi siku duduk dapat digunakan untuk mengevaluasi tinggi meja belajar (Taifa dkk., 2017). Tinggi siku duduk diukur dalam posisi lengan bawah lurus horizontal membentuk sudut tegak dengan lengan atas. Titik nol instrumen pengukuran dapat dimulai dari SRP (Seat Reference Point) (Hadiwiyono, 2015).

2. Tinggi Lutut Duduk

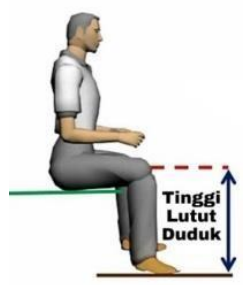

\section{Gambar 7. Tinggi Lutut Duduk}

Tinggi lutut adalah jarak vertikal dari lantai ke bagian atas lutut kaki (Hadiwiyono, 2015). Tinggi lutut dapat digunakan untuk mengevaluasi tinggi laci (Taifa dkk., 2017). Titik nol instrumen pengukuran dapat dimulai dari lantai (Hadiwiyono, 2015).

3. Lebar Sisi Bahu

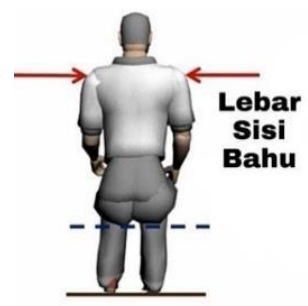

\section{Gambar 8. Lebar Sisi Bahu}

Lebar sisi bahu adalah jarak horizontal antara sisi paling luar bahu kiri dengan sisi paling luar bahu kanan (Hadiwiyono, 2015). Lebar sisi bahu dapat digunakan untuk mengevaluasi panjang meja belajar (Taifa dkk., 2017).

4. Panjang Genggaman Tangan ke Depan

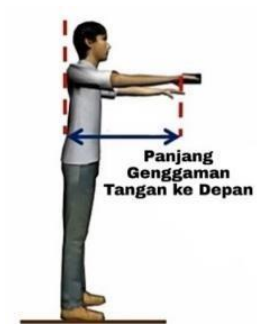

Gambar 9. Panjang Genggaman

Tangan ke Depan

Panjang genggaman tangan ke depan adalah jarak horizontal dari bagian belakang bahu ke pusat batang silinder yang digenggam oleh telapak tangan (Hadiwiyono, 2015). Panjang genggaman tangan ke depan dapat digunakan untuk mengevaluasi lebar meja belajar (Taifa dkk., 2017). 
Online: http://e-journal.sari-mutiara.ac.id/index.php/KesehatanMasyarakat

DOI: https://doi.org/10.51544/jkmlh.v6i1.1682

\section{HASIL}

\section{Karakteristik Sampel}

Penelitian pada anak sekolah dasar di sebuah sekolah dasar di Jakarta Utara menunjukkan karakteristik seperti pada Tabel 1. Siswa SD yang berpartisipasi dalam penelitian ini lebih banyak perempuan yaitu sebanyak 50 orang sedangkan laki-laki yaitu 48 orang dari total 98 orang dengan rata-rata berat badan dan tinggi badan anak laki-laki dari setiap kelas 1-6 SD lebih besar dibandingkan dengan anak perempuan. Peserta didik kelas 1-6 di sekolah dasar ini memiliki rentang usia 512 tahun.

\section{Ergonomi Meja Belajar}

Pengukuran meja belajar di sekolah dasar ini menunjukkan hasil seperti di Tabel 2. Rata-rata simpangan baku tinggi meja belajar, tinggi kursi, dan lebar meja belajar dari kelas 1-6 SD lebih rendah jika dibandingkan dengan ukuran tinggi laci. Ukuran tinggi meja, tinggi kursi, tinggi laci, dan lebar meja memiliki gap yang tidak terlalu jauh dari kelas 1-6 SD, sedangkan panjang meja belajar dari kelas 1-6 SD sama yaitu 60,5 .

Tabel 1. Karakteristik Responden

\begin{tabular}{|c|c|c|c|c|c|c|c|c|}
\hline \multirow[b]{2}{*}{ Kelas } & \multirow[b]{2}{*}{ Jml } & \multicolumn{3}{|c|}{ Laki-Laki (Mean \pm SD)(cm) } & \multirow[b]{2}{*}{ Jml } & \multicolumn{3}{|c|}{ Perempuan $($ Mean \pm SD) $(\mathrm{cm})$} \\
\hline & & $\begin{array}{l}\text { Berat } \\
\text { Badan }\end{array}$ & $\begin{array}{l}\text { Tinggi } \\
\text { Badan }\end{array}$ & Umur & & $\begin{array}{l}\text { Berat } \\
\text { Badan }\end{array}$ & $\begin{array}{l}\text { Tinggi } \\
\text { Badan }\end{array}$ & Umur \\
\hline $1 \mathrm{SD}$ & 5 & $23,6 \pm 6,3$ & $116,3 \pm 4$ & $5,8 \pm 0,4$ & 10 & $23,4 \pm 5,7$ & $112,8 \pm 6$ & $5,7 \pm 0,5$ \\
\hline $2 \mathrm{SD}$ & 7 & $25,2 \pm 6,5$ & $120,4 \pm 6,3$ & $6,7 \pm 0,5$ & 7 & $25 \pm 3,2$ & $119 \pm 3,7$ & $6,6 \pm 0,5$ \\
\hline $3 \mathrm{SD}$ & 10 & $26,4 \pm 3,1$ & $126,5 \pm 5,3$ & $7,8 \pm 6,7$ & 8 & $24,8 \pm 6,1$ & $122,3 \pm 7,6$ & $7,7 \pm 0,5$ \\
\hline $4 \mathrm{SD}$ & 9 & $40,4 \pm 11$ & $134,4 \pm 7,9$ & $8,8 \pm 0,4$ & 10 & $34,5 \pm 6$ & $133,4 \pm 5,9$ & $8,3 \pm 0,5$ \\
\hline $5 \mathrm{SD}$ & 8 & $40,6 \pm 12$ & $138,6 \pm 8,5$ & $9,8 \pm 0,5$ & 7 & $31,9 \pm 5,2$ & $134,8 \pm 7,9$ & $9,8 \pm 1,2$ \\
\hline $6 \mathrm{SD}$ & 9 & $44,5 \pm 13,7$ & $141,6 \pm 7,5$ & $10,9 \pm 0,6$ & 8 & $43,8 \pm 9,3$ & $144,7 \pm 8,8$ & $10,8 \pm 0,5$ \\
\hline
\end{tabular}

Tabel 2. Ergonomi Meja Belajar

\begin{tabular}{clccc}
\hline No. & \multicolumn{1}{c}{ Ergonomi } & Min & Max & Mean \pm SD \\
\hline 1 & Tinggi meja belajar $(\mathrm{cm})$ & 75,0 & 75,5 & $75,2 \pm 0,2$ \\
2 & Tinggi laci $(\mathrm{cm})$ & 58,5 & 65,0 & $61,8 \pm 3,2$ \\
3 & Panjang meja belajar $(\mathrm{cm})$ & 60,5 & 60,5 & $60,5 \pm 0,0$ \\
4 & Lebar meja belajar $(\mathrm{cm})$ & 40,0 & 40,5 & $40,3 \pm 0,2$ \\
\hline
\end{tabular}

\section{Antropometri Anak Sekolah Dasar}

Pengukuran antropometri anak SD di sekolah dasar ini menunjukkan hasil seperti di Tabel 3. Rata-rata simpangan baku dari kelas 1-6 SD tertinggi yaitu panjang genggaman tangan ke depan, dan yang 
terendah yaitu tinggi siku duduk. Rata-rata simpangan baku dari semua dimensi tubuh pada kelas 1 yaitu 2.25 dan tertinggi pada dimensi panjang genggaman tangan ; kelas 2 yaitu 2.325 dan tertinggi pada dimensi panjang genggaman tangan; kelas 3 yaitu 3.275 dan tertinggi pada dimensi lebar sisi bahu ; kelas 4 yaitu 3.325 dan tertinggi pada dimensi lebar sisi bahu ; kelas 5 yaitu 4.575 dan tertinggi pada dimensi tinggi lutut duduk ; kelas 6 yaitu 3.825 dan tertinggi pada dimensi panjang genggaman tangan. Berdasarkan data tersebut, setiap dimensi tubuh seperti tinggi siku duduk, tinggi lutut duduk, lebar sisi bahu, panjang genggaman tangan ke depan dari kelas 1-6 SD cukup bervariasi.

Tabel 3. Antropometri Anak Sekolah Dasar

\begin{tabular}{llcccccc}
\hline \multirow{2}{*}{ No. } & \multirow{2}{*}{ Dimensi Tubuh } & \multirow{2}{*}{ Min } & \multirow{2}{*}{ Max } & \multicolumn{3}{c}{ Persentil } & \multirow{2}{*}{ Mean \pm SD } \\
\cline { 5 - 7 } & & 12,0 & 27,5 & 13,5 & 17,5 & 23,6 & $17,8 \pm 3,1$ \\
\hline 1 & Tinggi siku duduk $(\mathrm{cm})$ & 32,0 & 55,0 & 36,9 & 43,0 & 50,7 & $43,8 \pm 4,8$ \\
2 & Tinggi lutut duduk $(\mathrm{cm})$ & 17,0 & 46,0 & 27,5 & 32,9 & 43,0 & $33,7 \pm 5,2$ \\
3 & Lebar sisi bahu $(\mathrm{cm})$ & 45,0 & 75,0 & 50,0 & 58,0 & 67,6 & $58,3 \pm 5,9$ \\
4 & Panjang genggaman tangan ke depan $(\mathrm{cm})$ & 45 &
\end{tabular}

Ketidaksesuaian Meja Belajar dengan

\section{Antropometri Anak}

Setelah data ergonomi meja dan data antropometri didapatkan, dilakukan analisis kesesuaian dengan menggunakan kriteria persentil antropometri siswa yang sudah disebutkan pada bagian Metode. Kriteria tersebut dapat menjadi acuan dalam mengevaluasi kesesuaian ergonomi meja terhadap antropometri siswanya. Kesesuaian ergonomi meja dengan data antropometri dapat dilihat pada Tabel 4. Tidak sesuainya ukuran adalah jika ukuran meja belajar lebih besar atau lebih kecil dari kriteria ukuran antropometri siswa berdasarkan persentil.
Berdasarkan Tabel 4, ketidaksesuaian antara ergonomi meja belajar dengan data antropometri anak sekolah dasar dialami oleh seluruh responden dengan meja belajar mereka di sekolah. Setelah itu, dilakukan perhitungan persentase ketidaksesuaian meja belajar dengan antropometri anak. Persentase ketidaksesuaian tersebut dapat dilihat pada Tabel 5. Berdasarkan tabel, rata-rata presentase ketidaksesuaian tinggi meja belajar yaitu 19,2\% ; tinggi laci yaitu $29,9 \%$; panjang meja belajar yaitu $61,1 \%$; lebar meja belajar yaitu $36,8 \%$. Rata-rata ketidaksesuaian yang terbesar terjadi pada panjang meja belajar, sedangkan tinggi meja belajar memiliki persentase ketidaksesuaian yang paling kecil. 
ISSN: 2528-4002 (media online)

ISSN: 2355-892X (print)

Online: http://e-journal.sari-mutiara.ac.id/index.php/KesehatanMasyarakat

DOI: https://doi.org/10.51544/jkmlh.v6i1.1682

Persentase ketidaksesuaian panjang meja

belajar tertinggi terdapat pada kelas 1

Tabel 4. Kesesuaian Meja Belajar dengan Antropometri Anak SD

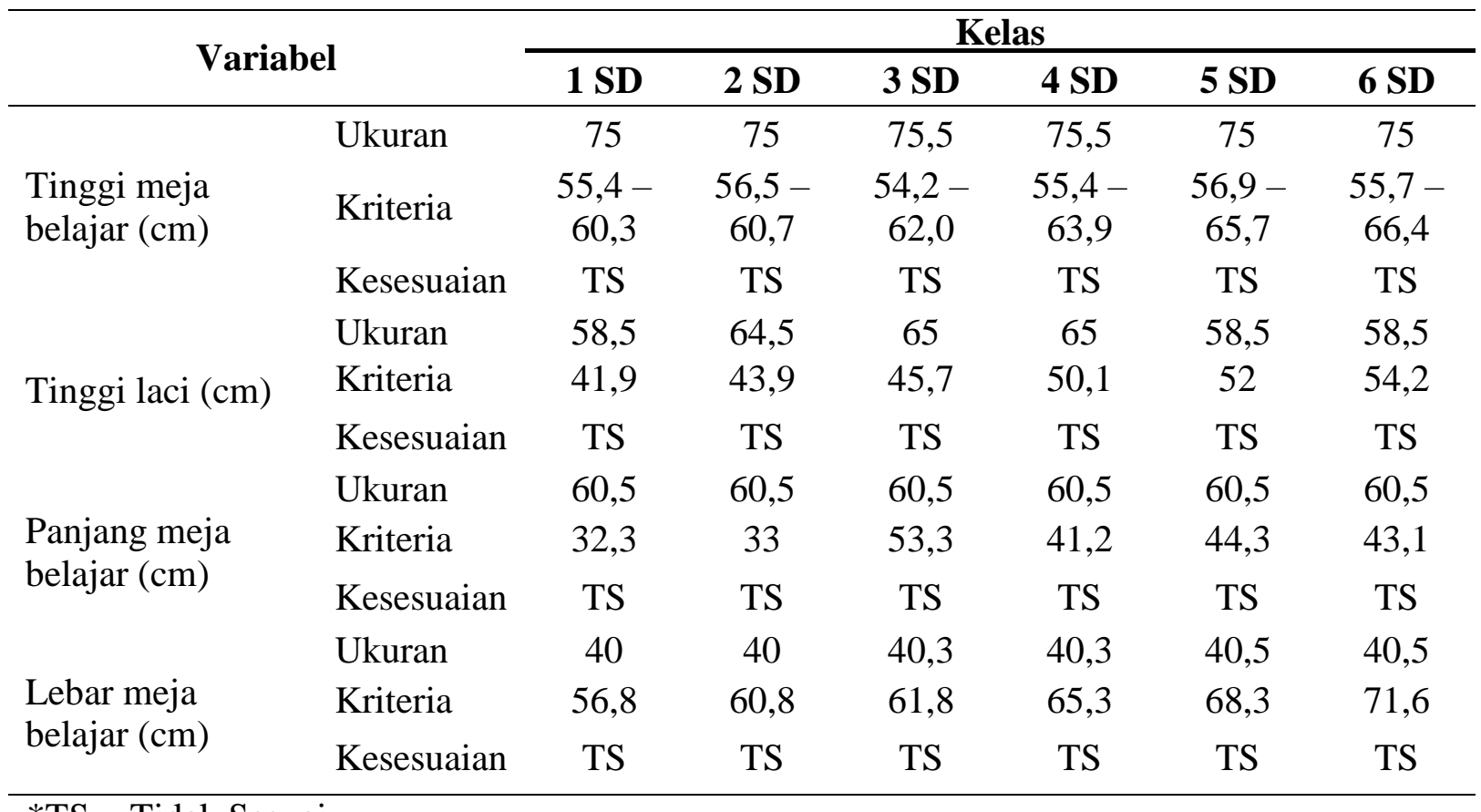

*TS = Tidak Sesuai

Tabel 5. Persentase Ketidaksesuaian Meja Belajar dengan Antropometri Anak SD

\begin{tabular}{llcccccc}
\hline Variabel & & \multicolumn{7}{c}{ Kelas } \\
\cline { 3 - 8 } & & $\mathbf{1}$ & $\mathbf{2}$ & $\mathbf{3}$ & $\mathbf{4}$ & $\mathbf{5}$ & $\mathbf{6}$ \\
\hline Tinggi meja & Terlalu pendek & 0,0 & 0,0 & 0,0 & 0,0 & 0,0 & 0,0 \\
belajar & Terlalu tinggi & 24,4 & 23,6 & 21,7 & 18,2 & 14,2 & 12,9 \\
\multirow{2}{*}{ Tinggi laci } & Terlalu pendek & 0,0 & 0,0 & 0,0 & 0,0 & 0,0 & 0,0 \\
& Terlalu tinggi & 39,5 & 47 & 42,4 & 29,9 & 12,6 & 7,9 \\
Panjang meja & Terlalu pendek & 0,0 & 0,0 & 0,0 & 0,0 & 0,0 & 0,0 \\
belajar & Terlalu panjang & 87,3 & 83,6 & 71,6 & 46,8 & 36,7 & 40,4 \\
Lebar meja & Terlalu pendek & 29,6 & 34,2 & 34,8 & 38,3 & 40,7 & 43,4 \\
belajar & Terlalu lebar & 0,0 & 0,0 & 0,0 & 0,0 & 0,0 & 0,0 \\
\hline
\end{tabular}

\section{PEMBAHASAN}

\section{Karakteristik Sampel}

Data karakteristik sampel diambil dari 98 siswa dari kelas 1 SD - 6 SD. Data yang diambil, yaitu jenis kelamin dan usia yang didapatkan dari hasil pengisian kuesioner serta berat dan tinggi badan yang diukur dengan menggunakan timbangan digital dan stature meter saat pengambilan data. Penelitian yang dilakukan pada 98 orang dari kelas 1-6 SD menunjukkan sebagian besar berjenis-kelamin 
perempuan, yaitu 50 orang. Berdasarkan Data Pokok Pendidikan Dasar dan Menengah Kementerian Pendidikan dan Kebudayaan menunjukkan bahwa jumlah peserta didik perempuan pada tahun ajaran 2019/2020 semester ganjil di sekolah dasar ini lebih banyak (228 orang) dari peserta didik laki-laki (216 orang) (Kemdikbud RI, 2019).

Berat-badan dan tinggi badan anak laki-laki dari setiap kelas 1-6 SD lebih besar dibandingkan dengan anak perempuan. Hal ini sesuai dengan hasil penelitian oleh (Damayanti dkk., 2017) yaitu berat dan tinggi badan peserta didik laki-laki lebih besar dibandingkan dengan berat dan tinggi badan peserta didik perempuan. Kemudian, berdasarkan grafik pertumbuhan yang dikeluarkan oleh Centers for Disease Control and Prevention (CDC, 2016), tinggi badan terhadap umur pada anak berada pada persentil yang bawah. Pada anak laki-laki, rata-rata tinggi badan berkisar antara persentil ke-25 hingga persentil ke-75 dan rata-rata berat badan berkisar antara persentil ke-50 hingga persentil ke-95. Pada anak perempuan, ratarata tinggi badan berkisar antara persentil ke-10 hingga persentil ke-75 dan rata-rata berat badan berkisar antara persentil ke-25 hingga persentil ke-90. Hal ini dapat menjelaskan alasan tinggi badan anak terhadap umur berada pada persentil yang bawah.
Peserta didik kelas 1-6 SD di sekolah dasar ini memiliki rentang usia 5-12 tahun, yang cukup berbeda dengan rentang usia anak SD pada umumnya (7-12 tahun), hal ini dikarenakan terdapat perubahan syarat usia penerimaan anak SD oleh Peraturan Menteri Pendidikan dan Kebudayaan Republik Indonesia No. 44 Tahun 2019, yaitu usia calon peserta didik baru kelas 1 SD paling rendah 5 tahun 6 bulan yang memiliki potensi kecerdasan dan/ataubakat istimewa dan kesiapan psikis yang dibuktikan dengan rekomendasi tertulis dari psikolog professional (Kemdikbud RI, 2019).

\section{Ergonomi Meja Belajar}

Berdasarkan hasil pengukuran meja dan kursi didapatkan bahwa ukuran tinggi meja, tinggi laci, dan lebar meja memiliki gap yang tidak terlalu jauh dari kelas 1-6 $\mathrm{SD}$, sedangkan panjang meja belajar dari kelas 1-6 SD sama yaitu 60,5. Sehingga, dapat ditarik kesimpulan bahwa rata-rata ukuran meja belajar dari kelas 1-6 hampir sama. Hal ini selaras dengan hasil penelitian oleh (Rosyidi dkk., 2016) yaitu furnitur ruang kelas di setiap sekolah tampaknya memiliki satu desain dan ukuran yang sama untuk semua kelas.

\section{Antropometri Anak Sekolah Dasar}

Berdasarkan hasil pengukuran data antropometri didapatkan bahwa rata-rata simpangan baku dari semua dimensi tubuh 
pada kelas 1 yaitu 2.25 dan tertinggi pada dimensi panjang genggaman tangan; kelas 2 yaitu 2.325 dan tertinggi pada dimensi panjang genggaman tangan; kelas 3 yaitu 3.275 dan tertinggi pada dimensi lebar sisi bahu; kelas 4 yaitu 3.325 dan tertinggi pada dimensi lebar sisi bahu; kelas 5 yaitu 4.575 dan tertinggi pada dimensi tinggi lutut duduk ; kelas 6 yaitu 3.825 dan tertinggi pada dimensi panjang genggaman tangan. Sehingga, dapat disimpulkan bahwa dimensi tubuh peserta didik di setiap kelas cukup bervariasi. Hal ini juga selaras dengan hasil penelitian oleh (Devinasari dkk., 2019) yaitu terdapat gap dimensi tubuh yang terlalu jauh dari kelas 1-6 SD.

\section{Kesesuaian Meja Belajar dengan Antropometri}

Setelah data ergonomi meja dan data antropometri didapatkan, dilakukan analisis kesesuaian dengan menggunakan kriteria persentil antropometri siswa yang sudah disebutkan pada Bab II. Terdapat ketidaksesuaian antara ergonomi meja belajar dengan data antropometri anak di sekolah dasar ini, yaitu sebesar 100\%, Setelah itu, dilakukan perhitungan persentase ketidaksesuaian meja belajar dengan antropometri anak dan didapatkan bahwa panjang meja memiliki persentase ketidaksesuaian terbesar, sedangkan tinggi meja memiliki persentase ketidaksesuaian yang paling kecil. Hal ini sesuai dengan hasil penelitian oleh (Yusoff dkk., 2016) yaitu dimensi furnitur SD di Putrajaya dan data antropometri anak sekolah tidak sesuai. Selain itu, penelitian yang dilakukan oleh (Angela, dkk., 2015) di Portugis dan (Rosyidi, dkk., 2016) di Indonesia samasama menunjukkan bahwa ergonomi meja belajar belum sesuai dengan dimensi tubuh peserta didiknya. Penelitian yang dilakukan oleh (Jennie, dkk., 2017 ; dan Novita, dkk., 2018) juga menunjukkan bahwa ergonomi meja belajar PAUD di Siwalankerto tidak sesuai dengan antropomteri anak peserta didiknya.

Kemudian, dalam penelitian ini juga ditemukan bahwa meja belajar tidak sesuai dengan kelas yang sesuai, seperti meja dengan ukuran yang lebih besar digunakan oleh siswa kelas bawah, padahal antropometri anak kelas atas dan kelas bawah sangat berbeda. Hal ini sesuai dengan hasil penelitian oleh (Rosyidi dkk., 2016) yaitu meja SD di Jawa Tengah dengan ukuran yang lebih besar digunakan oleh siswa kelas bawah.

Ada beberapa faktor mengapa terdapat ketidaksesuaian antara ergonomi meja belajar dengan data antropometri anak di sekolah dasar ini terjadi sebesar $100 \%$. Berdasarkan hasil yang didapatkan, meja dengan ukuran yang lebih besar digunakan oleh siswa kelas bawah. Selain itu, menurut (CDC, 2016), rata-rata tinggi badan anak 
Online: http://e-journal.sari-mutiara.ac.id/index.php/KesehatanMasyarakat

DOI: https://doi.org/10.51544/jkmlh.v6i1.1682

terhadap umur berada pada persentil yang bawah. Hal-hal ini dapat menjelaskan alasan ketidaksesuaian antara ergonomi meja dengan data antropometri terjadi sebesar $100 \%$.

Penggunaan meja belajar yang tidak ergonomis akan menyebabkan keluhankeluhan muskuloskeletal, seperti pada hasil penelitian oleh (Hiola, 2015) bahwa keluhan yang sering dirasakan, yaitu keluhan pada leher bagian atas, pergelangan tangan kanan, dan paha kanan. Keluhan ini paling banyak ditemukan karena tinggi meja yang tidak sesuai dengan siku duduk sehingga anak lebih cepat merasakan pegal di pergelangan tangan kanan karena anak harus meletakkan tangannya di atas meja yang terlalu tinggi (Yusoff dkk., 2016). Selain itu, keluhan yang dapat dirasakan yaitu pusing, lengan sakit, dan anak merasa lelah (Hiola, 2015).

Jika hal ini terus berlanjut dalam jangka waktu yang cukup lama, maka akan menyebabkan Musculoskeletal Disorders (MSD). MSD adalah cedera atau kelainan pada otot, saraf, tendon, persendian, tulang rawan, dan diskus spinalis. Work-related Musculoskeletal Disorders (WMSD) adalah kondisi dimana lingkungan pekerjaan dan kinerja pekerjaan berkontribusi secara signifikan terhadap gangguan tersebut dan diperparah atau bertahan lama karena kondisi ini. WMSD yang sering terjadi adalah Carpal Tunnel Syndrome (CTS), back injury dan back pain, serta artritis (CDC, 2020).

\section{SIMPULAN}

Ukuran tinggi meja, tinggi kursi, tinggi laci, dan lebar meja memiliki gap yang tidak terlalu jauh dari kelas 1-6 SD dan setiap dimensi tubuh seperti tinggi siku duduk, tinggi lutut duduk, lebar sisi bahu, panjang genggaman tangan ke depan dari kelas 1-6 SD cukup bervariasi. Terdapat ketidaksesuaian ergonomi meja belajar dengan antropometri anak sekolah dasar.

\section{SARAN}

Saran kepada pihak sekolah yaitu pihak sekolah perlu memperhatikan kondisi meja belajar yang dipakai anak muridnya apakah sesuai atau tidak, jika tidak sesuai perlu dilakukan desain ulang yang sesuai dengan peserta didik di tiap kelasnya.

Selain itu, diharapkan penelitian ini dapat dijadikan sebagai bahan referensi bagi penelitian selanjutnya mengenai dampak ketidaksesuaiannya ergonomi meja belajar dengan antropometri anak sekolah dasar di bidang kesehatan.

\section{REFERENSI}

Irham Bakri, Mulyadi. 2015. Analisis desain furniture belajar Sekolah Dasar Negeri di Kota Makassar: Sebuah analisis antropometrik. Prosiding; 9:TM10-1-TM10-8.

Yanto, Evi Situmorang, Herlina, Hotniar Siringoringo, Baba Md Deros. 2008. Mismatch between school furniture dimensions and student's anthropometry. APIEMS; 656-665. 
Wahyu Waskito Putra. 2018. Redesain meja dan kursi siswa di Yaketunis Yogyakarta. INVENSI; 3 (1):63-74.

Altaboli A, Belkhear M, Bosenina A, Elfsei N. 2015. Anthropometric evaluation of the design of the classroom desk for the fourth and fifth grades of Benghazi primary schools. Procedia Manufacturing; 3:5655-62.

Macedo AC, Morais AV, Martins HF, Martins JC, Pais SM, Mayan OS. 2015. Match between classroom dimensions and students' anthropometry: re-equipment according to european educational furniture standard. Human factors; 57(1):48-60.

Rosyidi CN, Susmartini S, Purwaningrum L, Muraki S. 2016. Mismatch analysis of elementary school furniture in several regions of Central Java, Indonesia, and redesign recommendations. SAGE Open; 6(3):2158244016664386.

Jennie Hasimjaya, Mariana Wibowo, Dodi Wondo. 2017. Kajian antropometri \& ergonomi desain mebel pendidikan anak usia dini 3-4 tahun di Siwalankerto. JURNAL INTRA; 5(2):449-459.

Novita Siaul, Mariana Wibowo, Taufan Rizqi. 2018. Analisis ergonomic terhadap desain mebel pada sekolah anak usia dini dengan antropometri anak usia 2-3 tahun. JURNAL INTRA; 6(2):83-93.

Sanders, M. S., and E. J. McCormick. 1998. Human Factors in Engineering and Design. 7th ed. New York, NY: McGraw-Hill.

Khaspuri GC, Sau SK, Dhara PC. 2007. Anthropometric consideration for designing class room furniture in rural schools. Journal of Human Ecology; 22(3):235-44.

Alrashdan A, Alsudairi L, Alqaddoumi A. 2014. Anthropometry of Saudi Arabian female college students. InIIE Annual Conference. Proceedings (p. 4075). Institute of
Industrial and Systems Engineers (IISE).

Kothiyal K, Tettey S. 2001. Anthropometry for design for the elderly. International Journal of occupational safety and ergonomics; 7(1):15-34.

Taifa IW, Desai DA. 2017. Anthropometric measurement for ergonomic design of students' furniture in India. JESTECH; 20:232-9.

Devinasari, N., Wibowo, M., Suprobo, F.P. 2019. Studi antropometri siswa Sekolah Dasar Negeri untuk desain mebel ruang kelas yang ergonomis di Kecamatan Wonocolo, Surabaya; 7(3):493-502.

Hadiwiyono C. 2015. Perancangan alat ukur antropometri untuk dimensi tubuh vertical dan horizontal. Sarjana Teknik. Skripsi. Jakarta: Universitas Khatolik Indonesia Atma Jaya.

Kementerian Pendidikan dan Kebudayaan. Data Peserta Didik - Dapodikdasmen [Internet].

Dapo.dikdasmen.kemdikbud.go.id. 2019._[sitasi 29 Agustus 2020].

Diambil dari: https://dapo.dikdasmen.kemdikbud.g o.id/sekolah/8FC275D603C74F3C3 DFE

Damayanti IAM, Junitha IK, Suaskara IBM. 2017. Pola pertumbuhan berdasarkan berat dan tinggi badan siswa pada sekolah negeri dan swasta di Kota Denpasar, Bali. Jurnal Biologi Udayana; 21(2):78 -87.

Centers for Disease Control and Prevention. CDC Growth Charts [internet]. 2016. [sitasi 22 Desember 2020]. Diambil dari:

https://www.cdc.gov/growthcharts/clin ical_charts.htm

Kementerian Pendidikan dan Kebudayaan. Peraturan Menteri Pendidikan dan Kebudayaan Republik Indonesia NO. 44 Tahun 2019 [Internet]. Kemdikbud. 2019. [sitasi 7 September 2020]. Diambil dari: https://jdih.kemdikbud.go.id/arsip/Pe 
Online: http://e-journal.sari-mutiara.ac.id/index.php/KesehatanMasyarakat

DOI: https://doi.org/10.51544/jkmlh.v6i1.1682

rmendikbud\%20Nomor\%2044\%20T ahun\%202019.pdf

Yusoff AAM, dkk. 2016. Mismatch between furniture dimension and anthropometric measures among primary school children in Putrajaya. Malaysian Journal of Public Health Medicine; 16(1):58-62.

Hiola R. 2015. Analisis keluhan muskuloskeletal siswa akibat penggunaan meja kursi yang tidak ergonomis di SDN 13 Kabila, Kabupaten Bone Bolango Provinsi Gorontalo. Universitas Negeri Gorontalo; 2399-2411

Centers for Disease Control and Prevention. Work-related musculoskeletal disorders \& ergonomics [Internet]. CDC. 2020. [sitasi 5 September 2020]. Diambil dari:https://www.cdc.gov/workplace healthpromotion/healthstrategies/musculoskeletaldisorders/index.htm 